\title{
CONTINUITY AND TRANSFORMATION OF RURAL COMMUNAL TEMPLES IN VIETNAM: A CASE STUDY OF TÂN CHÁNH VILLAGE, LONG AN PROVINCE
}

\author{
Ngo Thi Phuong Lan* \\ University of Social Sciences and Humanities, Vietnam National University - \\ Ho Chi Minh City, No. 12, Dinh Tien Hoang Street, District 1, \\ Ho Chi Minh City, Vietnam \\ E-mail: ngophuonglan@hcmussh.edu.vn \\ Nguyen Ngoc Tho ** \\ University of Social Sciences and Humanities, Vietnam National University - \\ Ho Chi Minh City, No. 12, Dinh Tien Hoang Street, District 1, \\ Ho Chi Minh City, Vietnam \\ E-mail: ngoctho@hcmussh.edu.vn
}

Published online: 30 July 2021

To cite this article: Ngo, T. P. L. and Nguyen, N. T. 2021. Continuity and transformation of rural communal temples in Vietnam: A case study of Tân Chánh village, Long An province. International Journal of Asia Pacific Studies 17 (2): 249-282. https://doi.org/10.21315/ijaps2021.17.2.10

To link to this article: https://doi.org/10.21315/ijaps2021.17.2.10

\begin{abstract}
Vietnamese communal temples (đình làng) were primarily established with two functions: (1) as a state-patronised institution to organise and control the village politically and culturally and (2) as a place of worship of village deities and meritorious predecessors. Both functions interact and complement each other-in many cases, the second serves as both a "means" and "technique" to deploy the first. However, nowadays the administrative role is no longer available; instead, the spiritual aspects are on the rise as a response to the increasing interaction of Buddhism, Caodaism, and folk beliefs as well as the impact of economic development and urban migration. Village elders learn to organise the temple into a communal socio-cultural institution, whereby cross-village temples have formed a cultural nexus of "power". This study finds that while several transformed into the form of "temple of heroes", Tân Chánh temple has been mobilised and transformed into a civic "religious and socio-cultural centre" at the grassroots


level. The socio-economic background of the area has caused such transformation. While the practical demand for communication and emotional exchanges among village members vividly ensures the continuity of the temple's tradition, the loss of direct state control paves the way for its transformation. Both continuity and transformation govern the current religious activities of Tân Chánh temple but there is always a challenge to compromise and integrate these two directions. However, the remaining function of god worship by which rituals are performed as "cultural agents" still binds the villagers together and gives them access to crossing boundaries.

Keywords: communal temple, continuity, transformation, Tân Chánh, southern Vietnam

\section{INTRODUCTION}

The dìn làng (communal temple) is a special political-cultural institution in pre-modern Vietnam which functions as a "prolonged hand" of the emperors in the village. In the regional context, the Vietnamese dinh làng functions similarly to the yamen in late imperial China. Đình làng was established with two main functions: (1) a state-patronised institution to organise and control the village politically and culturally, and (2) a place of worship of village deities and meritorious predecessors. Both of these functions interact and complement each other; in many cases the second works as a "means" and "technique" to effectively deploy the implementation of the first.

Being a state-patronised institution, the dinh làng was a "standardised" agent being continuously motivated by imperial orthopractic policies to ensure its vital goals. Watson (1985) in his notable theory of imperial standardisation of cultural practices in pre-modern China emphasised the role of the state and its crucial impacts on the "orthodox symbols" at the grassroots level such as gods, deities, state-patronised temples and other agents. In research on the imperial superscription of Guandi, the Chinese god of war, Duara (1988) further asserted that the imperial state sought to strengthen its political and ideological control over the population, especially those at the frontier regions, by standardising, sanctioning and superscribing local gods.

In another project on "political and ideological orthopraxy" in premodern Vietnam (2019), the authors pointed out that Vietnam once applied such a policy, especially the Nguyễn (1802-1945) in their territorial control 
of new frontiers in the south. As a result, dình làng were established and operated under state patronage in new lands. This system started to encounter turbulence and finally a decline in two periods: the French rule (the late 19th to early 20th centuries), and the high socialist transformation (1960s-1970s). Without imperial state patronage, many dinh làng came to decline while others transformed to adapt to the new situations. The dình làng of Tân Chánh Village is such a case of transformation. How did the Tân Chánh villagers manage to transform their temple? Was the transformation totally motivated by the change in the institution's essential structure or by the total impacts of external factors?

Pre-modern Vietnamese elites discussed and emphasised "standardised" functions of communal temples in their historiographical works such as Đại Việt Sư Ký Toàn Thu (大越史記全書, Complete Historical Annals of Đại Việt), Đại Nam Nhất Thống Chí (大南一统志, Unified Annals of Đại Nam), Gia Định Thành Thông Chí (嘉定城通志, Comprehensive Gazetteer of Gia Định Citadel) as well as travel notes Việt Điện U Linh Tập (越甸幽靈集, Collection of Stories on the Shady and Spiritual World of the Viet Realm) and Linh Nam Chich Quái (嶺南摭怪, Selection of Strange Tales in Lĩnh Nam), etc. These works mainly describe the origin of the dinh làng as a state-owned temple where the local administrative seat was located. The works largely emphasise the continuous orthopraxy that emperors of different dynasties deployed in order to ensure the dinh làng's political and ideological missions.

Modern research on communal temples bloomed from the last decades of the 20th century onwards when dozens of works were published in three main subthemes: (1) guardian god cult, (2) communal temples: origin, development and structure, and (3) communal temple festivals (see Sơn 2006; Huỳnh et al. 1993; Huỳnh and Trương 1997; Tạ 2006; Quách 1996; Nguyễn 2015). In addition to its political and religious functions, the communal temple also has important socio-cultural functions such as the venue for settlement of village lawsuits, communication, social networking, social work and cultural preservation.

While many authors and works discussed the basic functions of dình làng, only a few worked on its current transformation under the context-based perspective. Kirsten Endres (2002: 303-322) studied the changes in political and academic thinking in Vietnam from the 1960s to the end of the 20th century, showing many profound changes in the understanding of the role of traditional culture in national development discourse in the last two decades. Endres believed that in the late 1970s 
there was a new academic discourse on rural festivals among advanced scholars, which continued to be strongly stimulated by several wellknown cultural researchers in the 1980s and 1990s. Finally, this scholarly discourse played an important role in the restructuring of state policy and vision on traditional culture legacies. In another case study at Đại Bái village temple festival in northern Vietnam, Endres (2001: 95) confirmed that "the transformative dialogue between party-state ideology and traditional conceptions of moral community will be further continued at the grassroots of society". Collin Long (2003) studied the emerging Huế festival and concluded that "history and heritage are no longer purely shaped by the demands of revolutionary ideology" (p. 556). Hy V. Lương (2007) in the research on the restructuring of Vietnamese nationalism during the second half of the 20th century argued that "the changing notion of culture in the official discourse on the nation in Vietnam over the past half-century is rooted at least as much in the dialogic relation between the Vietnamese socialist state and local populations, as in the stronger integration of Vietnam into the global capitalist system" (p. 453).

This case study at Tân Chánh Village puts Bourdieu's (1977) concept of class reproduction to explain how the rich and the dynamic villagers in Tân Chánh learn to convert wealth into cultural capital, and then turn cultural capital back into wealth, in order to maintain their economic and social position. Both intrinsic and external factors referring to the transformation of Tân Chánh communal temple are investigated, while semi-structural interviews and ritual participation offer a variety of information and ideas for discursive analysis. In the later parts of the paper, the authors put the case study of Tân Chánh communal temple into ritual processing analysis under the vision of shared feeling and emotion through communal festival, especially Seligman and Weller's (2012) notion of mutual interaction between notation and ritual in creating shared experience among the ritual participants. This research also uses Pierre Bourdieu's concept of "class reproduction" to investigate and analyse the mobility of some local factors participating in Tân Chánh communal temple festivals. This case study is undertaken using a comparative approach between Tân Chánh communal temple and two other temples of both the same and different categories in the Mekong River Delta. 


\section{ĐİNH LÀNG AS A PROLONGED HAND OF THE PRE-MODERN STATE IN THE FRONTIER LANDS}

As described earlier, the Vietnamese dình làng possesses two main functions: state control and faith service. First of all, dình làng were erected to function as a governmental agency. The dình làng was the place where local officials worked and hosted higher-level mandarin officers and where orthodox rituals were regularly held dedicated to the guardian $\operatorname{god}(\mathrm{s})$ under the surveillance of provincial and central governments. In the old time, the village's Council of Notables would meet to discuss and settle all village affairs in đình làng (Endres 2001: 70)

The dinh làng might be born due to the demand for organising and controlling the villages. When a new village was formed, especially in the frontiers, the dình làng was built primarily to "mark" the official territorialisation of the state on the land. Many others had been primarily built by the villagers themselves as a meeting point of the entire new village, but later became state-patronised institutions. Therefore, the first and most significant function at the beginning was political validation and administration. Ngô Đức Thịnh (2012: 71) calls it "a collectivistic civil centre where village leaders and elderly elites held civic meetings". When the village became stabilised, the second function, that of the cultivation and standardisation of ideology and education, was added. Gods were honoured in the temple, and the school was established next to it. Tạ Chí Đại Trường (1986) has a different viewpoint, confirming that the dình làng originally served as a "stop-over hall" when the king and his mandarins paid visits to the local regions. A closely related idea is found in Đại Việt Sư Ký Toàn Thu in which the communal temple was officialised from generic military or civil relay stations during the Lý Dynasty (1010-1225). This purely administrative structure then turned into a communal temple when the central government ordered the commoners to erect altars to worship Buddhas and deities (see Huỳnh et al. 1993: 20). ${ }^{1}$ This suggestion of Tạ is not new, since Ngô Tất Tố already stated such idea in 1938 (see Ngô 1938/2018), and is still mentioned in some works of contemporary writers. However, in the authors' previous research on the earth gods of Vietnam, we found that only a limited number of "stop-over halls" were finally transformed into dình làng; instead, more dình làng were converted from local god temples or primarily built when the village was formed. 
Each village owns one communal temple. According to Minh Điều Huơng Uớc (Codes of Village Convention) by the Nguyễn Dynasty, only units of village level were allowed to erect dinh làng. Those of lower rank (such as hamlet, quarter, etc.) had to group with each other to form a village to qualify. In general, the main structure of dinh làng is divided into two parts: the main hall where the guardian god altar is set, and the front hall where rituals are performed and important meetings are held. According to Nguyễn Văn Khoan (1930), main rituals at dình làng lasted for hours in solemn order with preparation work done in advance. Standing with such a crucial role in village life, the dinh làng has long become an internalised symbol of Vietnam's rural tradition and widely reflected in folk art and literature. Being consolidated in the last orthopractic movement during the Nguyễn Dynasty, the đình làng is dubbed by Trần Ngọc Khánh "the brilliant cultural point of feudal Vietnam, especially the Nguyễn Dynasty" (Trần 2013).

The guardian god (thần thành hoàng) is believed to be the village's deity. They were first developed from local tutelary gods under the stategoverned orthopractic process in the Lê Dynasty (1428-1789). Many earth gods thus became village guardian gods, according to Việt Điện U Linh and Lĩnh Nam Chich Quái. For instance, the god of Phù Đổng village in Bắc Ninh province was "officialised" from a local earth god of Kiến Sơ temple built during the Lý Dynasty (1010-1225) (see Huỳnh et al. 1993: 14-16; Ngô 2012: 59). Guardian gods could be either historical figures that were deified or supernatural forces.

The standardisation of communal temples and guardian gods was strongly enforced during the early period of the Lê Dynasty (1428-1789). As noted in Bách Thần (百神, Hundreds of Gods), under the Lê Dynasty, the whole Đại Việt had 1026 dình làng including 944 establishments dedicated to Hùng Vương kings and their mandarins (Ngô 2012: 60). However, as the standardising process went on, subjects being worshipped such as Hùng Vương kings, mandarins, and other deities were generally conceptualised and sanctioned as "village guardian gods". Noticeably, the belief in guardian gods was not separated from Buddhism in those days. An order by Lê Thánh Tông in 1474 stated that each đình làng had to set up space for the worship of both the guardian god and Buddha (see Nguyễn 1930: 1-2; Huỳnh et al. 1993: 21). In 1496, King Lê Thánh Tông officially handed over the management rights of the dinh làng to the village, which strongly accelerated the collectivistic ownership of this institution. After Lê Thánh Tông, Confucianism became more officialised than Buddhism. 
Despite the fact that the worship of Buddhas was still maintained in many communal temples, official rituals were held under the Confucian mentality (see Ngô 2012: 60). Artistic performances dedicated to gods to legitimate the governance of the central court were "standardised" in each temple festival. Confucian rituals were superimposed on the dình làng, making it a tool for standardising village life and local traditions under the direct service of the villager-officials and local elites in embracing the Confucian civilising missions (see Thạch and Lê 1995; Hà and Nguyễn 1998; Taylor 2004: 43).

The đình làng in southern Vietnam are considered to be the extended model of the village temple in the north; however, they were strongly consolidated under the Nguyễn Dynasty. Communal temples in the south were expected to be erected under a unified code sanctioned by the Nguyễn rulers; therefore, to some extent, many of them largely bear more uniform features in comparison with those in the north (see further Huỳnh and Trương 1997). Unlike those in northern Vietnam, which were built in the very centre of the village, southern communal temples are mainly located along the rivers, canals and near local markets, landscaped by surrounding giant trees and other objects. Most of the surviving temples were rebuilt or restored in the early 20th century, and many of these have been further modified recently.

In general, southern communal temples are not big in size or delicate in aesthetic decoration. As codified by the Nguyễn rulers, the temples are divided into three categories, large, medium and small, depending on how large the population is and how important the temple is in its role. All dinh làng must include an outdoor altar dedicated to the earth in the front yard. Tigers, as one of the most dangerous wild animals during the reclamation process in the previous centuries, are worshipped at the small temples. The large and medium temples do not permit their worship since the tiger has not ever been sanctioned as a fundamental god of any village. Some of the local temples were built with generous donations from wealthy families, such as some in Bến Tre province sponsored by Madam Lê Thị Ngỡi in the late nineteenth century (see further Huỳnh et al. 1993: 25).

Most of the guardian gods worshipped in dinh làng in the south were sanctioned by the central government. In many parts of the region, they are unnamed; therefore, only a Chinese character "God" (神 Thần) is arranged at the back wall of the main altar. In other temples, co-worshipped deities are specified, e.g., emperors of the Lê Dynasty, Lord Cao Các, Lord Bạch Hạc, the earth god, Goddess Ngũ hành, craft gods, Goddess 
Inu Yana Ponager, local heroes, meritorious predecessors, etc. Guandi, the Chinese god of war, Tian Hou, the Chinese maritime goddess and some Indian-rooted gods are also co-worshipped. In 1804, Emperor Gia Long divided "guardian gods" into three ranks: upper (called thác cảnh thần), middle (quang y) and lower (linh phì); therefore, each temple has to show its hierarchical position by applying the accurate title of the god being sanctioned. Most of the unnamed "guardian gods" belong to the lower category. During the anti-colonial period, many deceased heroes were brought into dình làng without being sanctioned by the state, such as Nguyễn Hữu Huân (Thủ Khoa Huân) in Mỹ Tho, Trương Định in Gò Công, Nguyễn Trung Trực in Rạch Giá and four local heroes in Cai Lậy, etc. From the late 20th century onwards, many village temples started coworshipping Hồ Chí Minh as one of the "guardian gods" of the village.

Village temple festivals in southern Vietnam were mostly fixed in the lunar calendrical cycle in content and in form by the Nguyễn Dynasty. According to Huỳnh et al. (1993: 106-114), general activities include the year-end ceremony on 25th December, the lunar new-year liminal ritual, the farming initiation ritual on 7th January, the first, the 7th, and the 10th full-moon rituals and especially the Grand Prayer Festival (Lêe Kỳ Yên) normally fixed in the post-harvest period of August or September (lunar calendar). ${ }^{2}$ However, depending on the actual situation and many different reasons, some đình làng hold the annual Lế Kỳ Yên at other times of the year. The annual communal temple festival of Tân Chánh Village in this study is scheduled for the second month of the lunar calendar. Ritual offerings must include local farming products (pigs, sticky rice, vegetables, tea, wine, fruits, etc.) and fish from local rivers.

\section{ORTHODOXY, DE-ORTHOPRAXY AND TRANSFORMATION}

As a matter of fact, ritual brings people closer together if the fundamental symbol(s) being experienced and interpreted during ritualistic processes are well built. The elites of premodern East Asian states were in full consciousness of such impact; therefore, under the strict imperial doctrine and local bureaucratic support, đình làng and village deities were "standardised" (Watson 1985), "superscribed" (Duara 1988) and sanctioned. Most dinh làng in the south were sanctioned in 1852 under the reign of Tự Đức (1829-1883). ${ }^{3}$ Therefore, in the course of their existence, dình làng functions as a link between the village and the state, covering most of the 
village's "superstructural" activities and laying the foundation for each family to build a proper lifestyle. Villagers of every hue had to learn to be well-adapted to the obligatory process of orthopraxy; therefore, they were expected to fully acknowledge the role and impact of the central government on local villages. As a result, striving to attain the label of orthodoxy is one of the common features of traditional Vietnamese communal temples.

Together with the communal temple's structure and deity's sanctioning, rituals were also strictly institutionalised. According to Seligman and Weller (2012: 7), ritual means "primarily those acts that are formalised through social convention and are repeated over and over in ways that people recognise as somehow the same as before". Social convention in pre-modern Vietnam was much affected and mostly driven by imperial rules and principles. The emperor took advantage of rituals and symbols to "educate" and "civilise" his communities. This motivation can still be seen through the component of "Honouring the Kings" in the ritualistic performance.

Vietnamese commoners followed Lord Nguyễn Hoàng when he migrated from Đàng Ngoài (Tonkin, the North) to Đàng Trong (Cochinchina, the Central and, then, the South) in 1600; it was during the 1620 to 1650 period that the free farmers further migrated to the southern regions, followed then by the Chinese from overseas. Official state territorialisation was first made in 1698 under the reign of Lord Nguyễn Phúc Chu (1675-1725). Since then, dình làng in the southern regions gradually and profoundly transformed from a grassroots basis to orthopractic standards. Sorn Nam (2006: 21) remarked that a village was formed and the state's territorialisation made successful only when a state-patronised dinh làng was established. Otherwise, the village would turn into a so-called "collectivistic group of immigrants". In the beginning, the establishment of dình làng marked the continuity of the Vietnamese tradition in the new lands. On the other side, Trần Ngọc Khánh (2013) and Thanh Tiến (2015) emphasised that the erection of dình làng expresses the wishes and aspirations of the villagers in the new lands even though dinh làng has finally become state-patronised institutions. Villagers use their own way to interpret the dình làng, which does not necessarily meet the needs of government organisation and governance.

Since the pre-colonial period, especially in northern Vietnam, the budding of the de-orthopractic process appeared. The seeds of "de-orthopraxy" came along with the spirit of "anti-centralisation" of several local elites in northern Vietnam (sĩ tủ Bắc Hà) in the early 19th 
century since they were not satisfied with the rule of the non-Tonkinese Nguyễn rulers. ${ }^{4}$ As a result, some dình làng in the north have maintained aspects of their structure and activities rooted in the early and middle Lê Dynasty while others partially or completely transformed due to the village's specific convention and practical demands. One may see through communal temples in northern Vietnam both antiquity and diversity while in southern Vietnam uniformity and hierarchy.

During the French colonial era (1858-1945), dình làng's functions declined nationwide but did not collapse. The worship of anti-colonial heroes was added in several temples, especially in the south. Since then, dình làng was modified with more historical and social values, thus speeding up the de-orthopractic process.

The de-orthopractic process took place in southern Vietnam more strongly than in other regions. Many dình làng were removed by the colonialists to take their well-positioned lands to build their colonial offices and military posts. Since then, the communal temple system in the south was completely de-institutionalised and largely destroyed. Some of the village/community leaders (e.g., Trần Bá Lộc) $)^{5}$ were forced to work for the French interests, making people turn away from their longtime temples. Some temples and shrines in remote villages became a place of gathering for the insurgents, more or less being persecuted by the French, thus making the temple a symbol of the consolidation of local spirit and anti-French nationalism. Many others were tinged with the cult of Bà Chúa Xứ (the Lady of Realm) and other goddesses according to the spiritual needs of the villagers. Đinh làng in many provinces became the residence of the religious priests, indirectly becoming the birthplaces of a number of religious movements during the millenarian periods of the late nineteenth and early twentieth centuries. For example, Cầu Kho Temple in Ho Chi Minh City was the place where Caodaism's divination was initiated. ${ }^{6}$

In the time the Saigonese Government (1954-1975) organised a widespread political-civilian network, they reverted back to the former dình làng system and reunited it as means of control; therefore part of the communal activity was restored under a new paradigm of the institution and ideology. It is this that makes the symbol of the dinh lang sustain negative impressions in the minds of some post-war communist leaders.

It seems that the fundamental function of dình làng as a metaphoric image of the power of the feudal government made it a target of class struggle and the anti-superstition movement during the 1960s-1970s periods. At that time, the cults and festivals at dinh làng were considered 
"superstitious" and "depraved" customs' which contain "obsolete, corrupt and feudal characteristics" (see Endres 2002: 303, 306). Obviously, dình làng and its festivals are told to be important factors that stimulate "local consciousness" and fragmentation (Lê 1996: 24), maintain and promote the unequal structure in the village (Nguyễn 1959, 161-162). As a result, during the 1960s and 1970s period, dình làng and other village temples were used as administrative quarters, living quarters or village residence, cooperative warehouses, or market places. God and Buddha statues were stored in authorised temples and cult committees were accused of being "traitor landlords" (see Lương 1994: 94-96). The primary function of dình làng was severely damaged and destroyed; its spiritual domain was also affected. During this period, guardian gods were much transformed in their metaphoric meanings. They were no longer "the prolonged hands" of the rulers; instead, they "returned" to their ontological essence, the tutelary gods, and hid silently inside the faith of the commoners.

Economic reforms led to an innovative transformation of dình làng and its traditional activities. The new scholarly discourse on festivals during the late 1970s and further stimulation in the 1980s and 1990s have laid significant foundation in the restructuring of state policy and vision (Endres 2002: 303-322; Lương and Trương 2012). From the late 1970s to the early 1980s, the transformation of dinh làng institutions and festivals had a strong background, mainly based on the progressive views of Vietnamese anthropologists and historians such as Lê Thị Nhâm Tuyết (1976; 1978), Trần Quốc Vượng (1978), Lê Minh Ngọc (1978) (also cited in Endres 2002), etc. They strongly considered village festivals as 'a 'collective cultural activity' constituting an important national characteristic" (see Endres 2002: 306). Other scholars in the 1990s (e.g., Đinh 1994; Tô 1994; Ngô 1994; Trần 2014) strongly stimulated the reformist trend. These authors emphasise that a folk festival is a lively festival that not only reflects the ingenious aesthetic synthesis of traditional and modern elements in folk traditions but also reflects the foreign elements introduced through cultural exchanges.

More considerable and favourable factors have influenced the state discourse concerning the role of cultural traditions and history in the process of modern development (Endres 2002: 304). Lương (2007: 440) argued that the transformation would be "the dialogic relation between the Vietnamese socialist state and local populations, as in the stronger integration of Vietnam into the global capitalist system". As Vietnam's participation in the global economy increases, its official discourse "has 
embraced a wider range of past practices and allowed for the reconstruction of ritual sites as an integral part of Vietnamese identity and culture" (Lương 2007: 445). Under the new developmental discourse, dình làng and its related activities has transformed from allegedly "depraved customs" (hu tuc) to "pure and beautiful customs" (thuần phong mỹ tucc), and its feudal characteristics turned out to be subjects for the new discourse of "when drinking water, remember the source" (uống nước nhó nguồn). Lương conducted a significant case study in a northern village, namely Hoài Thị, and showed that major communal ritual sites have significantly and positively transformed since the last two decades of the second millennium (Lương 2007: 343). The national law on cultural heritage passed in 2001 further strengthened this transformation. In another village, Đại Bái, Endres (2001) found that the villagers' ritual attention "gradually shifted from the guardian deity to the craft ancestor, a process which reflects both the influence of party-state ideology and the villagers' struggle to preserve their local identity". Endres further argued that although reformist endeavor impacted village ritual life, it has failed "to 'root out' all of the former mechanisms by which male power and prestige are construed" (Endres 2001: 93-94).

On the other hand, dinh làng and its activities in the northern and southern regions have different experiences. In northern Vietnam, since communal temples were contextualised early, they were bound tightly with the villagers' interests and remained relatively independent from the Nguyễn Dynasty's control; therefore, the French rule did not seriously harm it. However, it was the high socialist periods of the 1960s to 1970 s that northern dình làng and its activities were severely damaged. Lương (1994), in a comparative study of the northern village of Son Duong and the southern village of Khanh Hau, concluded that the village festivals in the later were not severely damaged as in the former because the Marxist policies were implemented in a more moderate manner in the south (Lương 1994: 108). The similarity between the two regions is that the tradition is seen as a continuous and selective innovation process, playing a leading role in creating the past, linking the past with the present, and thus creating the future (Hobsbawm 1983; Sider 1986; Lương and Trương 2012).

Thanks to the 1986 Đổi mới (Reform) policy, the state started designing a cultural heritage policy, which was finally passed in 2001. Thus old establishments and legacies have been honored. Some typical temples ranked as provincial and district relics are prioritised in the restoration of architectural structures and ceremonies. The website of the 
provincial government of Long An province recently published a series of three articles on communal temples' current values, asserting that dinh làng carry value in "find[ing] the long-lasting roots" [of the Vietnamese people], are a "...historical-cultural symbol" [of the community] and are "the soul" of the nation" (Ngọc and Phương 2018). Current local authorities started sponsoring them culturally and financially, hence a part of the traditional đình làng system has been recovered. In such a policy, village guardian gods once again transformed their metaphoric implication. They were openly interpreted as tutelary gods among the people and became symbols of traditional legacies of rural Vietnam. Some dình làng became the headquarters of local folk art troupes, martial art associations or craft villages' memorial centres. For example, Cầu Quan temple in Ho Chi Minh City became the headquarters of Vịnh Xuân Troupe while Nam Chơn temple was transformed to host Nam Huỳnh Đạo Martial Art Group. The policy also opened a pathway for the revitalisation, addition and further development of popular religions within the temple's spiritual structure. Many dình làng in the Mekong Region were converted into temples of Bà Chúa Xứ, earth god, Guandi, etc. The authors' research in Thoại Sơn district of An Giang province showed that the 2001 policy on cultural legacies created the motivation to transform local communal temples. Those located at the district town and semi-urban centres re-opened and stabilised their original cult of Thoại Ngọc Hầu, ${ }^{7}$ Phan Thanh Giản ${ }^{8}$ and Nguyễn Trung Trực ${ }^{9}$ while those in remote corners re-opened and maintained the spiritual function of the traditional dình làng. In another field research, the dinh làng of An Cư village in Cái Bè district, Tiền Giang province, is not excluded. During the post-war period, the temple was used to store the village's cultural artefacts while the surrounding space was used as the school-yard for a middle school opened next to it. Such a situation remained until the year 2000 when the local government moved the school to another location. The temple was re-opened and gods' altars re-arranged. However, after two decades of being abandoned, the temple festival was re-organised with limited participation of the villagers.

Two post-war decades marked the turning point of the dình làng system when strong secularism and the class struggle mindset were overwhelmingly applied. Many temples were abandoned and destroyed while guardian gods were ignored and communal festivals closed. Guardian gods did not disappear; instead, they were preserved disguised in the fundamental flow of spiritual life of the commoners. It was the 2001 cultural legacies policy that untied the restraint towards this rural symbol, giving 
way to the re-opening of communal temples, and the return of the guardian gods and communal festivals. However, under the cultural heritage doctrine, these practices have been summarised as a legacy of the traditional rural culture where state management and surveillance are still applied. The dình làng functions as a "living museum" of the rural past. Gods are read as tutelary deities, and festivals are held regularly as "thanksgiving festivals". After more than three decades since the 1986 Đổi Mới policy, there is possibly a fourth wave developing, wherein many dình làng manage to transform once again to re-mobilise the villagers' active role at the temple. There are two main types of dinh làng to be mentioned, the historical hero temple and guardian god temple. Each has deployed its particular way of development. The Đinh làng dedicated to heroes try to maintain their faith structure while innovating on festival activities by reintroducing artistic performances and modernised means of recreation. The case study of Tân Chánh village in Long An province described in the following part belongs to this group.

The second type comprises of the temples dedicated to "generic" village guardian gods. The core symbolic figures, thus, are relatively blurred (unconcentrated). During the authors' fieldwork trips in 2014 and 2015, several dình làng in Thoại Sơn district belonged to this type. They share some common features such as small festivals with limited participation of the local villagers and limited activities except for core rituals and post-ritual collectivistic feastings. However, many other temples are dynamic, and the local community is skillful in taking advantage of the side function of the festival to mobilise and motivate communal resources and dynamism. Vĩnh Bình temple in Vĩnh Bình district of Tiền Giang province is a crucial case where a large-scale commercial trade fair is attached to the temple festival.

In the context of the above-mentioned research on the structure and functions of dình làng and its associated gods and festivals, and based on the survey data on worship in the Mekong regional communities, especially the long-term study in Cần Đước district of Long An province in 2010, the next part of the article will show that the current rituals of worshiping guardian gods in a specific location of the Mekong region. In addition to meeting the religious needs, the temple's function of social cohesion is increasingly strengthened through the circulation of "social exchanges" during the network of local and inter-village religious communities. The authors of the article share a view with Lương (1994) when it is considered that there is a positive relationship between economy and 
ritual. According to Lương (1994: 437-438), the economic surplus has greatly strengthened rituals inside and outside the families. Rituals and the reciprocal party system have strengthened social relations.

\section{THE RECENT TRANSFORMATION AT ĐİNH LÀNG OF TÂN CHÁNH COMMUNE}

Tân Chánh is a remote lowland commune of Cần Đước district, with a population of 12.136 people (in 2009) and a natural area of 1,700 ha, of which 990 ha is of agricultural land, 830 ha of shrimp farming. Due to the system of two large rivers, Vàm Cỏ and Rạch Cát, Cần Đước's land is characterised by a system of rivers and canals, and some communes are affected by salinity, the most severely impacted of which is Tân Chánh. These are two important natural features, regulating the traditional economic activities of this land. Before the period of raising shrimp, Tân Chánh was considered the poorest commune in the district due to saline soils and low productivity of rice cultivation. People in this period had to emigrate to earn a living away from home, most notably "boat commercialisation", exchanging goods between Ho Chi Minh City and the Mekong region. Based on floating boats, the village opened a barge-building factory. By 2010, the whole commune had over 500 barges to offer cargo transportation services. Since 2000, people have completely shifted from rice cultivation to shrimp farming, making this new product the main agricultural livelihood.

The name Tân Chánh first appeared in 1871 in "Nam Kỳ Địa Hạt Tổng Thôn Danh Hiệu Mục Lục" (Lists of Local Districts in Southern Vietnam). Residents in Tân Chánh since the founding of the village in the 18th century have established a network of religious institutions: one Caodai temple, some Buddhist pagodas, one dình làng, and several small deity shrines. In this system, the đình làng of Tân Chánh has a particularly important position in the life of the commune residents. If religious institutions like Caodaism and Buddhism only attract followers of their faith and the deity shrines are to serve their surrounding quarters, dình làng is the central place for all residents of all sources.

Currently, there is no document recording the exact time of birth of the Tân Chánh communal temple. However, the process of remodelling the communal house is currently clearly remembered by the people. Before 1961, according to Mr. N.V.O. (84 years old, the descendant of the liturgical master of the temple in that period), when the dinh làng was 
completely burnt due to a bomb explosion, the temple was quite large with more than 50 pillars made of high-quality wood. Deities were moved to be "stored" at the descendant house of Mr. Nguyễn Khắc Tuấn ${ }^{10}$ in Cần Đước market. Beginning in 1974, with the contributions of the villagers, the đình làng was rebuilt. In 2006, the whole structure was further modified, including the main building, front hall, guest houses, communal gates, and the kitchen. The temple is currently located on a campus of $3,301 \mathrm{~m}^{2}$ (see Long An Provincial Museum 2011: 9). Previously, a small part of the land belonging to the dinh làng was taken to build a nursery school. Besides, the Tân Chánh temple's campus is also the place to erect the memorial stone dedicated to the local martyrs. The dinh làng was recognised as a historical-cultural relic at the provincial level in 2012.

The main deity of the temple is called Thành Hoàng Bổn Cảnh (本境城隍, the guardian god). The embodiment of the "guardian god" is a wooden, rectangular, red plaque with the Chinese word 神 (Thần/God) gilded in the middle. The temple also co-worships mandarin Nguyễn Khắc Tuấn and Nam Hải Tướng Quân (General of the South Seas). Due to his merits towards the country, general Nguyễn Khắc Tuấn is co-worshipped.

Currently, some dình làng are playing the role of the centre of the cultural and social activities of the community and are the venues for hamlet meetings. The temple's annual festival is held on the sixth day of the second lunar month, which is considered the death anniversary of general Nguyễn Khắc Tuấn. The Grand Prayer Festival has become increasingly developed in terms of organisation. In the interpretation of local attendees, in addition to praying for communal security and well-being, there is also a close link to the present-day market economy through the great participation of many business people, especially those working on boats and barges. The present festival is no longer an internal activity of the locality; it shows very strong interactions within the regional network and with other forms of religious faith such as Caodaism, Buddhism, goddess cults, etc. All the villagers prepare to organise and participate in the annual Grand Prayer Festival. After nearly 20 years of switching from rice cultivation to shrimp farming, the villagers still maintain these occasions to pray for the development of the community; however, they switch to pray for shrimp cultivation instead of rice farming.

To perform the sacrificial work, villagers set up a temple communal committee (or đình cult committee), called Ban Hội Hưong Đình, which consists of "older, socially prestigious" men in the community and heads 
of the previous committees. This committee is sometimes adjusted based on patrilineal inheritance within the term of operation. If a member of the committee passes away during his tenure, his son will replace the position. The list of committees serving the 2009/2010 term has up to 30 members. The committee is in charge of deciding the associated issues, including ritualistic and communicative activities at neighbouring communes and, importantly, organising the Grand Prayer Festival. Unlike the head of the committee whose term is two years, members of the financial unit are voted on annually among the local wealthy families and large business operators. Because the festival is mainly based on the villagers' voluntary contributions, the heads of duty always pay in advance for logistics, purchases and all other preparation work. They will be reimbursed after the festival. If the festival's public contribution is in surplus, construction and embellishment of the temple will be invested in further; however, if there is not enough money to pay back those who paid in advance, the reimbursement will be made in the next festival season. Like in other dình làng in the south, the Grand Prayer Ritual of Tân Chánh temple takes place over two days including the Lễ Tống Phong (Exorcism Rite), Lễ Thỉnh Sắc (Imperial Seal Roll Rite), Lễ Xây Chầu Đại Bội (Salvation Rite), Lễ Thinh Sanh (Sacrifice Offering Rite), Lễ Túc Yết (Initiation Rite), Lễ Chánh Tế/Đoàn Cả (Main Prayer Rite) and a ritualistic art performance to close the festival.

The influence of the on-boat business and barge service sectors on the festival is also reflected in the Lế Tống Phong (Exorcism Rite) held on the morning of the fifth day of the second lunar month. Previously, the committee members built wood- and paper-made boats to release on the rivers with the desire to drive away the misfortune. If the rite goes well (when the boat does not capsize and is not hit back by waves), people believe it is a sign of a favourable year. If this ceremony does not go well, one must repeat the ceremony at a later date. Exorcism boats are built exactly in the model of tugboat barges, which are typical for a profession that brings prosperity to the local community.

The Imperial Seal Roll Rite is held at noon on the fifth day of the second lunar month. Villagers following liturgical masters join the procession to receive the roll to hold a short ritual at the tomb of general Nguyễn Khắc Tuấn in Lăng Hamlet, about $300 \mathrm{~m}$ away from đình làng. After this ceremony, the temple enters the period of the Main Prayer Rite. 
The main ritual at the temple is a combination of a guardian god's thanksgiving rite and a hero's anniversary rite. Due to the consensus of the villagers toward the meritorious general Nguyễn Khắc Tuấn, the festival is also called the "anniversary of the guardian god".

The festivals of the years 2000, 2003, and 2007 took place on a large scale since these years coincide with the three-year cycle, the cult committee organise Lê̂ Xây Chầu Đại Bội for two main purposes (as informed by the liturgical masters): exorcism and praying for security and wealth. Since 2008, due to the active participation of the well-off families in the cult committee and festival organisation committee and the participation of their invited guests in the festival activities, the temple has received a sufficient budget (orally provided by Mr. N.V.L., 62 years old, head of the đinh cult committee, 25 August 2020). Therefore, the rite Lê̂ Xây Chầu $Đ a i$ Bộ $i$ and other large-scale festive activities are organised every year. This rite was strictly regulated by the Nguyễn rulers and has been kept unchanged until the present day. Normally, this rite is held after the main rite. Liturgical masters and village leaders are requested to bow collectively by the main ritualistic performers on the ritual ground. Only professional drama artists are invited to perform such a significant ritualistic ceremony. Dramatic performances are strictly arranged according to yin-yang (âm duoong), three-power (tam tài) and five-element (ngũ hành) philosophies, ending with an performance of the tôn vuoong rite (honouring the kings) (Huỳnh et al. 1993: 158-190). Only special parts of specific dramas such as San Hậu, Phụng Nghi Đình or Thần Nũu Dâng Ngũ Linh Kỳ $\grave{y}^{11}$ are performed at this moment. Under a discursive viewpoint, this rite is to legitimise and empower the Nguyễn rulers in the new frontier lands.

In the following years, due to a large amount of money collected from the participants, the performances have been organised annually. According to the oral statements of local informants, attendance at the temple began increasing between 2004 and 2005. Largely when wealthy businessmen joined the communal committee, the participating population thus expanded. Previously, people participating in the festival had been mainly local people and the authorities. Thanks to the involvement of business owners in the committee (aged around 45 to 55 years old), the festival at Tân Chánh has become a "diplomatic" platform. They utilise the festival opportunity to expand their network relationships, thereby enhancing reputation and expanding business resources. This "cultural capital" is much appreciated by both members of dình cult committee and villagers. While the main work and ritualistic performances are fulfilled 
by cult committee members and their fellows, public participants of dình hamlet where the temple is located join the peripheral work. People of other hamlets merely come to join the rituals and share the collective meal since they consider all the work to be dình hamlet's privileged service.

Most participants are men and women of middle age or older. The offerings include fruit, sticky rice, little cakes, money, and especially pig's heads. There is always a committee member available to record the contribution amount of the participants. In preparation for receiving participants, a month earlier, the committee has to send out invitations to the local villagers and guests from the neighbouring communes. Inviting guests has been strong for the past decade due to the participation of "giant" economic households in the committee and the approval of the local authority. Many people originating from Tân Chánh village who work away from home are expected to return to attend the festival. In the 2010 festival, in addition to many villagers who offered agricultural products (such as rice, pigs, chickens, aquatic products, fruits and cakes), 700 groups and individuals donated a total of VND100 million, which matches the costs of organising (VND80 million) and the honorarium for the ritual music troupe (VND20 million). In 2017, the cash amount collected increased to VND190 million which made a surplus of 70 million after paying all expenses. Previously, the villagers contributed mainly homemade agricultural products, fruits or cakes, but recently, several have shifted to money thanks to the increasing incomes from farming shrimp. As the head of the temple committee remarked, "the better an economic status people have, the more they participate in the festival".

"Borrowing money from god" is a long-lasting tradition of the Vietnamese people, from which the congregants of Tân Chánh temple are not excluded. In 2010, the committee reserved VND30 million for this service. As shared by Mr. N.V.H. (48 years old, committee member), "the largest amount for individual lending is VND500,000". The villagers pay the money back before the next festival season. The service's interest depends on each individual. In the same year, the committee also set up a mutual aid fund serving the committee members and those who were in need. The interest from this fund was used to cover the shortfall in the annual festival. There were 60 households requesting a loan in the first year and this number keeps increasing yearly.

The relationship between dinh làng and Caodaism is also shown in the ritual ceremony. Sacrifices were performed by ritual participants under the guidance of "the liturgical master" (Mr. N.V.T., 75 years old, resident 
of Đình Hamlet). Before the main ceremony, prayers for communal security and "deceased soldiers" are held at dinh làng with the participation of Caodaism followers. Due to the small number of junior followers, Tân Chánh's Caodai temple is not able to establish a ritual music band. To organise this ceremony, Caodai masters request the service of the professional Caodai ritual music band from Tây Ninh province. On other occasions, the local Caodai temple often invites the band from the neighbouring Long Hựu temple. Mr. B.T.L. (80 years old), a member of the temple's communal committee, said:

We invited the Caodai ritual band from Tây Ninh to pray for our community. Because we have a Caodai population living in the commune, if not, they will be so sad. Caodaism is a religion, similar to other ones... They pray for the martyrs and those who lost their lives for the community. Previously, our temple had a financial shortfall, and there was no way to invite them because we had to cook vegetarian food to serve them. (Interview report, 2010)

Whenever there is a financial need, members of the temple committee pay tribute to cover expenses such as financial assistance for ill member(s), participation at other temples' activities, communication costs, etc. In case of a shortfall, wealthy members of the committee pay in advance and will be reimbursed after the main festival the following year. Villagers of Tân Chánh commune also eagerly participate in the family-based death anniversary ceremony of general Nguyễn Khắc Tuấn on the lunar calendar equivalent of 16th February at his tomb. Like the main festival at dình làng, the ceremony at the tomb has been changed from a small-scale ceremony during the previous periods into an event of mass public participation in recent years.

Along with economic development, the festival has also become an occasion for "exchange". Guests invited by the committee include local authorities, as well as members of inter-village communal temple networks inside and outside the province. The festival in 2010 witnessed the participation of several representatives of various dình làng in Ho Chi Minh City and provinces of the Mekong Delta region. There are two forms of attending the ritual, as an independent participant or as a registered one. Local residents arriving as individuals get in line, offer tribute(s) and bow to the gods before joining the collective meal while distant guests arriving in groups are asked to register in advance and wait until called to make their offerings. Offerings by distant groups usually include trays of fruit, incense, 
candles, and cash (usually VND500,000 or VND1 million in 2010 and VND1 million to VND2 million in 2017). Members of these distant groups may pay more sacrifice money if they can afford. In 2010, 20 distant groups of guests participated in the festival, while the number in 2017 was 35 . Mr. L.V.L. (50 years old), a member of the committee who owns a shrimpraising farm in Tân Chánh said:

Previously, some old men ran the committee, and they had to consider a lot before spending the money. At that time, I had only made contributions as an individual donor. Later I found myself getting older, and I needed more confidence to do stronger business, so I stood as a candidate to join the committee. Business people have a stronger belief in god since they encounter many unexpected issues. If you burn an incense stick and bow in front of the gods, it will make you more confident because the gods will always bless you. I believe, so I do it. Later, when I took the committee job, I invited my friends to join my business, mainly my barge-serviced fellows, and they were eager to join me. They alternatively contributed VND500,000 or VND1 million. As I talk about the holiness of the guardian gods, people believe and are willing to contribute. When the festival comes, we invite them. Later, when they have a festival in their local village, we will also participate enthusiastically. The committee will assign its members to take turns participating. We have to sacrifice as much as they do to our temple festival.

The relationship between economic and spiritual needs is evident in the involvement of local business owners in the duties of the temple committee. As Mr. B.T.L. (80 years old, member of the Tân Chánh dình làng cult committee) said:

A few years ago, it was difficult to find members for the financial unit of the committee because of the fear of losses. Surplus money collected during the festival must be put into the temple's fund. But if it is not enough, the temple can only pay the money back after the festival of the following year. Now wealthy families voluntarily register to participate in the temple duties because they believe that doing good deeds can make their business better.

Thus, in the context of present-day society, dình làng is a cultural institution from feudal times that has still maintained its inherent important functions: communal cohesion among different groups of people in the village (regardless of faith, economic background, and social status) and 
reinforcement of spiritual faith among the villagers and local businessmen who have in mind the motto "to worship is to generate and cultivate goodness". The religious function of the ritual rites still preserves the nature of supporting the residents' agricultural livelihoods even if they shift from rice farming to shrimp farming. The shrimp goes into the vows and wishes towards the guardian gods. Additionally, when studying communal rites in Tân Chánh temple as a model of the southern Vietnamese communal temple, the authors found that the social functions of the temple have been expanded. The temple's rituals not only have a cohesive function within the village community but also expand socio-economic links to other localities. It is this expansion that makes the temple festival more attractive and effective. The transformation from a low-yield wet rice farming economy to market-oriented shrimp farming has enabled people to contribute to the ceremony. In addition, the existence of a lot of economic activity in the community is also important for promoting the social relationships of the temple festival. In the opposite direction, the ritual ceremony is solemnly organised and the scale makes the social relationships develop and co-operate to bring about economic and social benefits for all engaging parties.

\section{THE COEXISTENCE OF CONTINUITY AND TRANSFORMATION OF THE 円İNH LÀNG IN CONTEMPORARY SOUTHERN VIETNAM}

Recent dinh làng festivals still operate on the axis of mutual interaction between religious and social functions as previously in history. Emile Durkheim once divided the whole world into the sacred and the profane domains. Rituals at a village temple are bound with both aspects. Born as institutions of both social and religious interests, Vietnamese communal temples, to a certain extent, still maintain their cultural and religious functions regardless of severe repression in the post-war years. However, they do not serve the political interests of the ruler like they once did during the pre-modern periods; instead, communal ideology and practices are emphasised these days. As Seligman and Weller (2012: 7) put it, "we usually think of ritual as dealing with the sacred world alone, but in fact, the basic structure of every single ritual is to cross the boundary between the sacred and profane, not simply to play in the world of the sacred". In the recent rise of popular materialism and modernisation, today's communal festivals 
draw more attention to secular life, such as minimising the gap(s) in social and economic strata, calling for the return of those who have left the village for education and business (in the case of Tân Chánh village), creating the side function of promoting local commercialisation (in the case of Vĩnh Bình village), mediating the differences in interests between the community and the authorities (in almost all dinh làng across the region), etc.. Therefore, there have been the conflicts and ambiguities among the communities. The religious mechanism has been "consolidated" as the means of this mediating mission.

The dình làng's festival, as we see in the case of Tân Chánh village, functions as a symbolic, self-reflective performance that brings people "out of the ordinary" in order to reflect the communal values and aspiration and to create the shared experience of community (see Alexander 1991: 24) as well as bring the past to the present. Aside from this symbolic function, the shared feeling in the ritual process truly opens up a direct and specialised opportunity to new "potentiality" of transformation. Turner and Turner (1985: 126) emphasises that rituals can "mediate between individual unconscious impulses and intentions and the social processes of the group making for its cohesion and continuity". As stated by a high-ranking liturgical board member in Tân Chánh village, the annual temple festival must be held regularly to direct and guide people to the goals of village consolidation and civilisation. He furthered that temple ritual is currently the only way that allows people of different backgrounds "to sit and share". As demonstrated in our fieldwork observations, participants increase yearly, and they keep an optimistic and open-minded attitude during their communications.

Similarly, these communal festivals promote the validation and reinforcement of common values widely acknowledged by the villagers in this long-running tradition of farming communities in rural Vietnam. Although đình làng no longer serve as a state agency in the village, their cultural and social implications largely remain. In the cultural domain, both the ancient temple itself and the temple festival acted as a channel to re-affirm the validation and reinforcement of both family-based Confucian merits (such as loyalty, patriotism, filial piety, family hierarchy, etc.) as well as and community-based values (such as standardised ideology, social hierarchy, righteousness, humaneness, etc.). These merits were carried in both temple-related symbols (and objects) and festival activities. In the current situation, except for loyalty and social hierarchy, the other merits are still protected and expressed in festivals. In the social domain, almost 
all functions are continuously preserved and being asserted in the modern festival: orthopraxy, solidarity, boundary-crossing, tension reduction, etc. In summary, with the exception of the political discourse, the communal festivals have almost entirely preserved their "continuity" after a long and uneasy historical journey in Vietnam.

Communal rituals in contemporary Vietnam play a strong role in "teaching us to live with differences and all their associated ambiguities" (Seligman and Weller 2012: 8), thus implementing tension reduction. There are three interactive modes to handle boundaries: "notation", "ritual" and "shared experience". Notation refers to the basic symbolic implications of the communal temples, gods, and ideological structure embedded in those establishments. Notation generates the main ideas that festival participants are expected to perceive. Noticeably, notation is cultivated and can be restructured or modified by those who are legitimised to govern the festivals. Ritual, the concentrated practice at the temple at a certain time in the annual calendrical cycle, functions as an open and collectivistic platform where the notation is truly transformed and embedded into the mindset of the participants. Members of the festival are "kept separate yet must also maintain friendly ties" (see Radcillfe-Brown 1952: 90-104). "Shared experience", the outcome of the rituals, is what the festival organisers expect to spread among the villagers in accordance with the new potentiality of social transformation and progress. As Seligman and Weller (2012: 9) describe, "the nature" of the "intermix" between those three factors "helps to construct alternative historicities and socialities". Shared experience, as we understand, can only help cross boundaries. It does not extinguish the difference or ambiguity.

In the case of Tân Chánh village, as well in other places across the Mekong River Delta, the shared experience generated from the festival's shared feeling and emotion has motivated participants as well as those who have reached such experience through other means (such as communication) to cross the ambiguities (in Seligman and Weller's [2012] term) present in their real life. This ambiguity is generated from the sharp difference between Marxist ideology in a socialist state (Vietnam) and the spiritual life of religious communities. This tension has been contributed to by the loosening of the state's control on religions since the 1986 Đổi mới Policy. The rituals bind those who leave the village with those who stay. Furthermore, the rituals attempt to put side by side the long-time agricultural tradition of the village and the newly-emerging shrimp-raising and marketbased economy, in which local elites (festival actors and local authority) 
seek an acceptable model of pluralism in terms of cultural and social conventions. These above-mentioned binary complexes express another intrinsic feature of the contemporary festival in Tân Chánh village: a binary combination of both internal solidarity and external communication. As told by an old-aged participant, "participants in Tân Chánh largely belong to Buddhism and Caodaism. Some are Catholics, the rest non-religious; however, we are happy to see that they all put aside their personal faith to integrate into the temple festival. You can't see a similar situation at a non-festival event these days!".

However, one may ask: "Does the festival in Tân Chánh village itself possess adequate magnetism to put all the differences in harmony?" The answer is no. In the authors' observation, it must be the efforts and assertion of the local elites and businessmen who join the executive and liturgical board of the temple to mould the core symbolic meanings and the ritual orders of the whole festival that motivate and sharpen the integration and pluralism. The communal festival is understood as a common elaborating symbol, which strongly depends on specific background (see Turner 1967). Although Turner (1967: 96-97) advocated anti-structural potential in the ritual process, he did not negate the former structure, but used it in a "strategic" or "perspectival" way (Turner 1974: 272). He suggested that anti-structure and structure are "intrinsically related, perhaps, even... not contradictory in the ultimate, non-dualistic sense" (Turner 1974: 44-45; also cited in Alexander 1991: 42). Turner's anti-structure stands in dialectic relation to structure, making ritual "a concrete response to the shortcomings of a particular social structure" (Alexander 1991: 38). As an antithesis of social structure, anti-structure "relaxes participants' obligation to the structural differentiations that mediate everyday social intercourse (e.g., role, status, etc.) and, in so doing, allows for directness and experimentation in human interaction and makes possible social changes" (Alexander 1991: 39). The main actors of the festival greatly influence the arrangement (and re-arrangement) of the ritual structure and its human resources to close the distances and cultivate a strong sense of belonging among the villagers. On the foundation of the consciousness of the eternal motherland in each Vietnamese individual, this additional strong sense of belonging has effectively built up a sense of responsibility (towards the village) among those who leave.

Another ambiguity, if not the most uneasy one, comes from the opposition between administrative (or political) agency and cultural power. The ancient communal temple covered both political and cultural powers; 
however, the present-day separation between the state-owned people's committee office and dình làng has opened an opportunity to put cultural power in hands of the villagers, who directly govern and operate the temple activities. The village temple executive board proactively registers and applies for permission at the communal People's Committee whenever they want to hold a temple festival. Furthermore, they actively coordinate with business sectors to support the implementation of charity work under the auspices of the authorities. These activities signify the compliance of the villagers towards the local authority; in return, state agencies provide permission, observe the festival activities, judge the legality of the festival, and look for contributory ideas (or comments) from the participants. Thanks to this initiative, the conflict(s) between these two types of power have been reduced.

Communal festivals in contemporary Vietnam generate and motivate social change. Since difference (or ambiguity) still exists in reality, there is always a demand for resolving it which leads to social transformation. As Geertz (1973: 142-169) highlighted, ritual shapes the social order and also "shape the conflicts in society" by "cross[ing] a threshold [limen] into another order of existence", thus it contributes to social change. Beers (1992: 53) furthered that ritual helps create and express both social and psychological transformation. In the temple festival, both the organisers and participants associate symbols such as god(s), symbolic objects, symbolic practices, etc. with the god's efficacy and their own aspirations. Notation, as Seligman and Weller (2012) asserted, contains both primary meanings and newly-cultivated symbolic ideas, which causes the dramatic transformation of the communal festival. Current activities held at Tân Chánh village are no longer to honour royal merits or to provide a means for political control or offer villagers guidance in how to comply with the law; instead, they convey the collective voices and cultural power of the community. Such a transformation can be also found at Vĩnh Bình temple in Tiền Giang province and Tầm Vu temple in Long An province. The Vĩnh Bình temple festival has fully resumed its annual festival in recent decades, but it is closely attached to the year-end trade fair, so it can attract a large number of participants. The Tầm Vu temple festival has no other choice but to expand the side function of exorcism to bring back the participants. In Tầm $\mathrm{Vu}$, despite the solemn homage of village deities and local heroes, during the festival, people may find it more attractive due to demon-like disguise activities and exorcism rituals. Accordingly, the representatives of each quarter of the village organise a group of hungry ghosts. A well-trained group arranged by the temple cult committee will play 
the roles of Đường Tăng ${ }^{12}$ and his apprentices, defeating the demons to protect the villagers. The villagers in all hamlets respectively and eagerly participate in the hungry ghosts groups, strongly expressing the unified engagement of the villagers to form a common voice for "communication" with the local authorities and the outside world. In northern Vietnam, Lương and Trương (2012) point out in the study of dình làng festival in Hoài Thị Village that the lively festival expresses a process of continuous creation of "tradition" by villagers. This process involves multivocality. The state plays an important role in management activities, but national policies are not always implemented during festivals. Instead, Hoài Thị's đình làng festival is a narrative stage for different groups, where many aspects of "tradition" have been reorganised and reinterpreted.

In addition to creating a shared experience, communal festivals in Vietnam open a platform upon which experimental ideas are suggested and applied, local business experience and shrimp-farming expertise are shared; thus, the festival, under the motivation of the shared feeling and emotion, generates new steps toward the progressive evolution of the village. In Tân Chánh village and across the whole region of Mekong River Delta, during the festival season, the meritorious and rich families are honoured for the merits of their contributions, both administrative, in festival organising engagement, and financial; therefore, they are willing to share experience and business opportunities. The recognition of meritorious persons, in turn, inspires the other families to build a strong commitment to their own business and causes them to increase the degree to which they are invested in the upcoming temples festivals. In Bourdieu's (1977) words, the commercial sector (e.g., shrimp farmers and barge owners) has taken full advantage of their active participation, extensive exchanges, and generous donations to the Tân Chánh temple festival to nurture and improve their reputation and communication resources. Over the years, this mental wealth (cultural capital) has continued to be transformed into resources serving their business, thereby indirectly promoting local economic development. As Vietnam participates in the development of the world market, this phenomenon may not be unique. However, so far, we have not seen similar situations in other field work sites in the Mekong Delta. Although the social hierarchy tends to be strengthened and promoted through the extensive and in-depth participation of the local business sector, ordinary villagers enjoy many benefits, such as experiential learning opportunities, cooperation opportunities, outbound networking opportunities, and job opportunities. Perhaps most importantly, 
both the business sector and ordinary villagers will benefit from the vitality of local social and economic development. As many villagers told us, "Có thờ có thiêng, có kiêng có lành!" (You'll experience sacredness if you venerate the god(s), and you'll enjoy protected comforts if you comply with sacred taboos). More and more villagers in Tân Chánh are willing engage in communal festivals for both spiritual merits and social reputation. During the festival period, those who left the village are also eager to share their new knowledge and practices, which they learned or self-generated during their stay in urban areas such as Ho Chi Minh City. In return, they bring back to the cities their village inspiration and aspirations, which improve their emotional quality of life. Communal festivals are thus a role-player in mediating the gap between the rural and the urban, the rich and the poor, the elites and the popular; therefore, they function as a source of transformation.

In sum, in comparison with the ancient tradition, dìn làng in contemporary Vietnam perform both continuity in cultural education as well as social solidarity and transformation in social evolution. This binary structure takes place under the prerequisite condition of political demobilisation and ideological de-standardisation within the context-based re-structuring and operation of dình làng.

\section{CONCLUSION}

The dình làng and its festivals have experienced several ups and downs during both pre-modern and modern Vietnamese history. It was first formed and patronised by the feudal state for its territorialising and civilising missions at the grassroots level. The dình làng was, thus, standardised and superimposed orthodox Confucian values even though Buddhism and popular beliefs were also encouraged for villagers to partake in. Such orthopraxy declined during French colonialism and was totally abolished after the Vietnam War. Marxist ideology and the socialist regime of the later period further abandoned the dinh làng since it was assumed to be "the legacy of class stratification". Thanks to its close attachment to the villagers' emotional mindset, the dinh làng was still protected by the community. In 2001, the new national cultural heritage law was passed and dinh làng was categorised as a part of traditional culture.

The rural community, in reality, is dynamic in preserving, transforming and remodelling new facets of dình làng. Under the impact 
and participation of the economic field, dình làng and its festivals have turned into special platforms of multi-lineal interactions between several binary forces: the old and the new, the internal and external, the cultural and the social, the spiritual and the secular, the rural and the urban, and the community and the state. The interaction does not help abolish the differences and tensions; however, the revitalisation of dinh làng festivals brings people closer together, helping them temporarily cross those boundaries through the festival's ritualistic effects. Furthermore, the rituals during the festivals directly promote a sense of belonging among the villagers and those who were born in the village but left. Consequently, dình làng and its festivals in many places have been widely re-modeled and/or re-acknowledged as common symbols of the villagers of all sources in modern times. The Tân Chánh communal temple is such a case.

The increasing number of participants in dình làng festivals has enhanced its capacity to carry and transmit "collectivistic power" and the communal voice of the rural society. Such a discursive situation has ensured the dialogic role of dinh làng and its festivals in dealing with the state via the local authority. As a matter of fact, dình làng has long been transforming from the status of an order-abiding institution into a dialogic meeting point of all social forces. Symbolically, dinh làng has become a "socio-cultural mediator" of contemporary rural Vietnam. The economic field (in Bourdieu's [1997] words) and local elites' mobility are two main factors that make such a transformation possible.

\section{ACKNOWLEDGEMENTS}

This research is funded by Vietnam Foundation for Science and Technology Development (NAFOSTED) under grant number 603.05-2019.01.

\section{NOTES}

* Ngo Thi Phuong Lan is Associate Professor in Anthropology, majoring economic and social anthropology. Her expertise is in Vietnamese rural farming, rural development, and rural communities, especially the Mekong Delta, under the strong process of internationalisation and global warming. She got her master's degree in the University of Toronto (Canada) and PhD degree in Vietnam National University - Ho Chi Minh City. She is a United Board visiting scholar to Harvard University in 2017. Ngo Thi Phuong Lan is the author of five books and 40 articles and book chapters published in domestic and foreign journals and edition books. 
** Nguyen Ngoc Tho is Associate Professor in Cultural Studies, majoring in East Asian and Vietnamese folklore and social ritual studies. He concentrates on rituals, customs and daily life of the Vietnamese and ethnic Chinese peoples under the East Asian perspective. He obtained his $\mathrm{PhD}$ degree in Vietnam National University - Ho Chi Minh City, was a visiting scholar to Sun Yat-sen University in 2008, the Harvard-Yenching Institute during the 2017/2018 academic year, Harvard University's Asia Centre in 2018/2019 and Boston University in 2019/2020. Nguyen Ngoc Tho is the author of five books and more than 40 journal articles published in Vietnam and overseas. He holds the co-authorship of dozen other books, book chapters and journal articles. He is currently a member of the Standing Committee of The National Foundation for Science and Technology Development (NAFOSTED) of Vietnam (Council of Culture, Arts, and Tourism).

1 According to Ngô Đức Thịnh, the Trần Dynasty (1225-1400) rulers ordered each village to stabilise the worship of Buddhas in the communal temple in 1231. The Lê Dynasty (1428-1789) furthered this policy by legitimating private temples built by the commoners (Ngô 2012: 59)

2 Trịnh Hoài Đức in Gia Định Thành Thông chi stated that local village temples in the south hold Lễ Kỳ yên in August or September according to the state-sanctioned schedule in the history of the Nguyễn Dynasty. The authors of this research believe that this statement is a coincidence to the main reason why such festivals are organised in August or September, the post-harvest season.

3 During 1852, Emperor Tự Đức sanctioned a total of 13,069 temples nationwide (see Trịnh 1820-1822).

4 The Tây Sơn Dynasty (1789-1802) was built by Emperor Nguyễn Huệ and the Nguyễn by Emperor Gia Long, both started from the Central and southern Vietnam.

5 See Ho Tai (1983: Chapter 3), Brocheux (1995: 15), etc.

6 The hybrid religion took shape in 1926 in southern Vietnam under the combination and integration of ancestor worship, Buddhism, Taoism, Confucianism, Catholicism, and other religions.

7 Thoại Ngọc Hầu or Nguyễn Văn Thoại (1761-1829) was a high-ranking mandarin under the Nguyễn Dynasty. He was appointed by Gia Long Emperor to dig the irrigation canals of Vĩnh Tế and Thoại Hà in An Giang province, opening a pathway for the immigration and land opening in the deep basin south of Mekong Rivers.

8 Phan Thanh Giản (1796-1867) was a high-ranking mandarin under Tự Đức Emperor who failed to defend Vietnam against the attacks of the French and was finally forced to sign the treaty to give away the Mekong region to the French in 1867. Phan committed suicide one week after. Post-war historians condemned him the betrayer; however, the villagers of some communes in the Mekong Region worship him in their communal temples.

9 Nguyễn Trung Trực (1838-1868) was a local leader of the anti-French movement in the Lower Mekong Region. Under his leadership, Vietnamese patriots were mobilised widely across the region and organised several revolts against the French colonialists. He was finally captured and executed by the French in Rạch Giá on 27th October 1868. He was deified to be the guardian god of many local temples in the region. 
10 Nguyễn Khắc Tuấn was a martial mandarin of the late Nguyễn Dynasty who was deified to be the co-worshipped deity of Tân Chánh temple. He was ordained by King Minh Mạng on 3rd March 1823 (see Long An Provincial Museum 2011).

11 These works come from Chinese culture, but they were accepted and re-edited by the Nguyễn Dynasty in Vietnamese style and were performed and interpreted by Vietnamese in a local way. The detail is that a prince is awarded the sword and the seal to crown the throne which exactly legitimises and asserts the enthronement of the first emperor of the Nguyễn Dynasty, Gia Long, after his conquest of the Tây Sơn Dynasty by armed forces.

12 Đường Tăng (唐僧 Tang Seng, or 唐三藏 Tang Sanzang), a great monk of the Tang Dynasty in China, was sent to India to acquire official Buddhist scriptures. He and his four disciples were romantically depicted in Wu Cheng-en's work, The Journey to the West (西遊記), in the 16th century. Accordingly, they conquered a total of 81 disasters caused by evils and heterodox forces to protect the people and safely carry out their imperial missions.

\section{REFERENCES}

Alexander, B. C. 1991. Victor Turner revisited: Ritual as social change. Atlanta, GA: Scholars Press.

Beers, W. 1992. Women and sacrifice: Male narcissism and the psychology of religion. Detroit, MI: Wayne State University Press.

Bourdieu, P. 1977. Cultural reproduction and social reproduction. In Power and ideology in education, ed. Karabel, J. and Halsey, A. H., 487-511. Oxford: Oxford University Press.

Brocheux, P. 1995. The Mekong Delta: ecology, economy and evolution, 1860-1960. Madison, WI: University of Wisconsin-Madison.

Duara, P. 1988. Superscribing symbols: The myth of Guandi, Chinese God of War. The Journal of Asian Studies 47 (4): 778-95. https://doi.org/10.2307/2057852

Đinh, G. K. 1994. Hội lễ dân gian truyền thống trong thời hiện đại [Traditional folk festivals in modern times]. In Lê̂ hội truyền thống trong đời sống xã hôi hiện đại [Traditional folk festivals in modern times], ed. Đinh, G. K. and Lê, H. K., 25-32. Hanoi: Social Sciences.

Endres, W. K. 2001. Local dynamics of renegotiating ritual space in northern Vietnam: The case of the "dinh". Journal of Social Issues in Southeast Asia 16 (1): 70-101. 2002. Beautiful customs, worthy traditions: Changing state discourse on the role of Vietnamese culture. Internationales Asienforum 33 (3-4): 303-322.

Geertz, C. 1973. The interpretation of cultures. New York: Basic Books.

Hà, V. T. and Nguyễn, V. K. 1998. Đình Việt Nam [Vietnamese communal temples]. Ho Chi Minh: Hochiminh City Publishing House.

Ho Tai, H. T. 1983. Millenarianism and peasant politics in Vietnam millenarianism. Cambridge, MA: Harvard University Press. https://doi.org/10.7591/97815017 18991-017 
Hobsbawm, E. 1983. Introduction: Inventing traditions. In The invention of tradition, ed. Hobsbawm, E. and Ranger, T., 1-14. Cambridge, UK: Cambridge University Press. Huỳnh, N. T., Trương, N. T. and Hồ, T. 1993. Văn hóa dân gian cổ truyền: Đình Nam Bộ, tín nguỡng và nghi lễ [Traditional folklore: The earth god, the faith and the figurines]. Ho Chi Minh: Hochiminh City Publishers.

Huỳnh, N. T. and Trương, N.T. 1997. Đình Nam bộ xuaa và nay [Communal temples in southern Vietnam: Now and then]. Dong Nai, Vietnam: Đồng Nai Publishing House.

Lê, M. N. 1978. Tín ngưỡng Thành hoàng và ý thức tâm lý cộng đồng làng xã [The belief in Guardian deities and the psychology of village community spirit]. In Nông thôn Việt Nam trong lịch sư [The Vietnamese countryside in history], Vol. 2, ed. Viện Sử học [Institute of History], 337-348. Hanoi: Social Sciences.

Lê, Q. Đ. 1996. Thực trạng lễ hội dân gian cổ truyền ở nước ta hiện nay [The current situation of traditional folk festivals in our country]. Văn Hóa Dân Gian 1: 21-24.

Lê, T. N. T. 1976. Nghiên cứu về hội làng ở Việt Nam. Vị trí lịch sử của hội làng [Research on Vietnamese village festivals. The historical position of village festivals]. Dân Tộc Học 1: 48-59.

. 1978. Các loại hình hội làng trước cách mạng [Forms of village festivals before the revolution]. Dân Tộc Học 2: 13-23.

Long An Provincial Museum. 2011. Lịch sủ văn hóa đình Tân Chánh và Lăng mộ Nguyễn Khắc Tuấn [Cultural history of Tân Chánh temple and general Nguyen Khac Tuan's tomb]. Long An, Vietnam: Long An Provincial Museum.

Long, C. 2003. Feudalism in the service of the revolution: reclaiming heritage in Hue. Critical Asian Studies XXXV: 535-558.

Lương, V. H. 1994. Cải cách kinh tế và tăng cường lễ nghi tại hai làng ở miền Bắc Việt Nam, 1980-1990 [Economic reform and ritual enhancement in two villages in northern Vietnam, 1980-1990]. In Nhüng thách thức trên con đường cải cách Đông Duong [Challenges on the path of reform in Indochina], ed. Ljunggren, B., 437-481. Hanoi: National Politics Publishing House.

2007: The restructuring of Vietnamese nationalism, 1954-2006. Pacific Affairs 80 (3): 439-53.

Lương, V. H. and Trương, H. C. 2012. Thương thảo để tái lập và sáng tạo "truyển thống": Tiến trình tái cấu trúc lễ hội cộng đồng tại một làng Bắc bộ [Negotiation to re-establish and to invent "tradition": The re-structuring of community festival in a north Vietnamese village). In Nhũng thành tưu nghiên cứu bước đầu của Khoa Nhân học [Primary research achievements of the Department of Anthropology], ed. Department of Anthropology, Vietnam National University - Ho Chi Minh City, 235-279. Ho Chi Minh City: Vietnam National University.

Ngọc, T. and Phương, P. 2018. Đình thần: Nơi lưu giữ nét văn hóa truyền thống [Communal temples: The "museum" of traditions]. www.longan.gov.vn (accessed 1 November 2019).

Ngô, T. T. 1938/2018. Tập án cái đình [Collected notes on communal temples]. Hanoi: Văn học. 
Ngô, Đ. T. 1994. Những giá trị văn hóa của lễ hội cổ truyền và nhu cầu của xã hội hiện đại [Cultural values of traditional festivals and the needs of modern society]. In Lê̂ họi truyền thống trong đời sống xã họi hiện đại [Traditional folk festivals in modern social life], ed. Đinh, G. K. and Lê, H. T., 283-292. Hanoi: Social Sciences. . 2012. Tín ngương và văn hóa tín ngương ở Việt Nam [Popular religions and their culture in Vietnam]. Hanoi: Trẻ.

Nguyễn, C. B. 2015. Lễ hội cổ truyền của người Việt, cấu trúc và thành tố [Traditional Vietnamese festival, structure and elements]. Hanoi: Social Sciences.

Nguyễn, H. P. 1959. Xã thôn Việt Nam [Vietnam's villages]. Hanoi: Văn Sử Địa.

Nguyễn, V. K. 1930. Essai sur le Đình et le culte du génie tutélaire des villages en Tonkin. Bulletin de l'École Française d'Extrême-Orient 30: 107-139

Quách, T. N. 1996. Hội đình của người Việt ở Thành phố Hồ Chí Minh [Communal temple festivals in Ho Chi Minh City]. Unpublished dissertation, Ho Chi Minh City Academy of Social Sciences, Vietnam..

Radcillfe-Brown, A. R. 1952. On joking relationships. In Structure and function in primitive society, ed. Radcillfe-Brown, A. R., 90-104. New York: Free Press.

Seligman, A. B. and Weller, P. R. 2012. Rethinking pluralism: Ritual, experience, and ambiguity. Oxford: Oxford University Press. https://doi.org/10.1093/acprof:oso/ 9780199915262.001.0001.

Sider, G. 1986. Culture and class in anthropology and history. Cambridge, UK: Cambridge University Press.

Sơn, N. 2006. Đình miếu và lễ họi dân gian miền Nam [Temples and popular festivals in southern Vietnam]. Hanoi: Trẻ.

Tạ, C. Đ. T. 1986. Một trú sở Việt của thần linh: Cái đình làng [A living space of Vietnamese village guarding gods: The communal temple]. Văn Học 8-9: 5-17; 10: 44-67. 2006. Thần, người và đất Việt [Vietnames gods, people and lands]. Hanoi: Tri Thức.

Thạch, P. and Lê, T. V. 1995. 60 lễ họi truyền thống Việt Nam [Vietnam's 60 traditional festivals]. Hanoi: Social Sciences.

Taylor, P. 2004. Goddess on the rise: Pilgrimage and popular religion in Vietnam. Honolulu: University of Hawaii Press. https://doi.org/10.1515/9780824844516

Thanh, T. 2015. Bản sắc đình thần Nam Bộ [The identity of southern Vietnamese village temples]. http://baoangiang.com.vn/ban-sac-dinh-than-nam-bo-a94851.html (accessed 1 November 2019).

Tô, N. T. 1994. Niềm tin và lễ hội [Beliefs and traditional festivals]. In Lễ họi truyền thống trong đời sống xã hội hiện đại [Traditional folk festivals in modern social life], ed. Đinh, G. K. and Lê, H. T., 267-274. Hanoi: Social Sciences.

Trần, L. B. 2014. Đình làng Việt: Châu thổ Bắc Bộ [Vietnamese communal temples in the Red River Delta]. Hanoi: Thế Giới.

Trần, N. K. 2013. Đình làng Nam Bộ: Một thiết chế văn hóa cổ truyền [Southern Vietnamese communal temples: A traditional cultural institution]. In Nhũng vấn đề khoa học $x \tilde{a}$ họi \& nhân văn [Issues in social sciences], ed. University of Social Sciences and Humanities, Vietnam National University - Ho Chi Minh City (USSH-HCM), 112-118. Ho Chi Minh: Vietnam National University. 
Trần, Q. V. 1978. Hội hè dân gian với làng quê đổi mới [Folk festivals and the renewed village]. Nghiên cúu Nghệ thuật 1 (18): 70-82/104.

Trịnh, H. Đ. 1820-1822. Gia Định thành thông chi [嘉定城通志, Comprehensive gazetteer of Gia Định citadel]. N.p.

Turner, W. V. 1967. The forest of symbols: Aspects of Ndembu ritual. Ithaca, NY: Cornell University Press.

1974. Dramas, fields, and metaphors: Symbolic action in human society. Ithaca, NY: Cornell University Press.

Turner, W. V. and Turner, E. 1985. On the edge of the bush: Anthropology as experience. Tucson, AZ: University of Arizona Press.

Watson, L. J. 1985. Standardising the gods: The promotion of Tien'hou ("Empress of Heaven") along the South China coast, 960-1960. In Popular culture in late imperial China, ed. Johnson, D., Nathan, A. J. and Rawski, E. S., 292-324. Berkeley, CA: University of California Press. https://doi.org/10.1525/978052 0340121. 